Article

\title{
Reaction of Lavandula angustifolia Mill. to Water Treated with Low-Temperature, Low-Pressure Glow Plasma of Low Frequency
}

\author{
Katarzyna Ciesielska ${ }^{1}$, Wojciech Ciesielski ${ }^{1, * \mathbb{D}}$, Tomasz Girek ${ }^{1}$, Henryk Kołoczek ${ }^{2}$, \\ Zdzisław Oszczęda ${ }^{3}$ and Piotr Tomasik ${ }^{3}$ \\ 1 Institute of Chemistry, Jan Długosz University, Armii Krajowej Ave. 13-15, 42201 Częstochowa, Poland; \\ k.ciesielska@ujd.edu.pl (K.C.); t.girek@ujd.edu.pl or grek@ujd.edu.pl (T.G.) \\ 2 Institute of Chemistry and Inorganic Technology, Krakow University of Technology, Warszawska Str. 24, \\ 31155 Krakow, Poland; Henryk.koloczek@pk.edu.pl or koloczek@indy.chemia.pk.edu.pl \\ 3 Nantes Nanotechnological Systems, Dolnych Młynów Str. 24, 59700 Bolesławiec, Poland; \\ oszczeda@stomadent.pl (Z.O.); rrtomasi@cyf-kr.edu.pl (P.T.) \\ * Correspondence: w.ciesielski@interia.pl
}

Received: 16 September 2020; Accepted: 7 November 2020; Published: 12 November 2020

check for updates

\begin{abstract}
Lavandula angustifolia was watered with either deionized tap water treated with low-temperature, low-pressure glow plasma of low frequency in the air (LPGPA), under oxygen-free nitrogen (LPGPN), methane (LPGPM), carbon dioxide (LPGPC) or molecular oxygen (LPGPO). The crop yields were slightly dependent on the type of water used for watering. Notably, only plants watered with LPGPN showed a slightly higher crop yield. The plants also contained a higher level of protein and bioaccumulated magnesium. The type of water had a considerable and specific effect on the yield of isolated essential oils and their composition. The yield of essential oil decreased in the following order LPGPA $=$ LPGPN $(0.4 \mathrm{~g} / 100 \mathrm{~g}$ dry mass $)>$ LPGPC $=$ LPGPO $(0.3 \mathrm{~g} / 100 \mathrm{~g}$ dry mass) $>$ LPGPM $=$ non-treated water $(0.2 \mathrm{~g} / 100 \mathrm{~g}$ dry mass). The composition of the isolated essential oils varied depending on the type of water used for watering, which influences their role as a fragrant component of cosmetics, and in herbal therapy and aromatherapy.
\end{abstract}

Keywords: aromatherapy; essential oils; fragrance; herbal medicine; lavender

\section{Introduction}

In 2009, a patent was claimed [1] for the equipment for treating water with a glow plasma (LPGP). LPGP was found to be different to other reported kinds of plasma [2-6] (see also the relevant literature survey in our recent paper [7]) because it does not break valence bonds; therefore, treatment with LPGP does not evoke any chemical reaction. Thus, single oxygen atoms, hydrogen peroxide and ozone cannot be formed when water is treated with LPGP in the air [8], as well as under molecular oxygen [9].

Following the invention of LPGP and the construction of a generator suitable for the treatment of water $[1,7,10]$, a series of papers were published on the specific physical and physicochemical properties of water treated with LPGP in the air (LPGPA) [8], under all oxygen-free nitrogen (LPGPN) [7], ammonia (LPGPAM) [11], methane (LPGPM) [12], carbon dioxide (LPGPC) [13], and molecular oxygen (LPGPO) [9]. Based on these various studies, the functional properties of such treated water could be applied to agriculture and various branches of industry, as well as human and animal prophylaxis and therapy.

The majority of previous studies have focused on LPGPA and have shown that LPGPA stimulates the reproduction and pathogenicity of entomopathogenic fungi; thus, it has often been employed 
as a biopesticide [14]. Also, fermentative microorganisms are stimulated by LPGPA and improve the quality of brewery barley and malt [15]. Murawski et al. [16,17] demonstrated the successful application of LPGPA in animal breeding. When ram and boar semen were preserved in this water, insemination was more efficient.

A number of studies have been performed in the area of agriculture, namely, in the maintenance of meadow, flower-bed grass and vegetable production (lettuce) [18], and herb breeding [19]. The effect of LPGPA and LPGPN are particularly interesting. Although the yield of crops of peppermint was hardly improved, the composition of the essential oils from the peppermint was considerably modified. These results imply that this might also be the case for other herbs.

In this paper, we present the effects of LPGP-treated water on the growth of Lavandula angustifolia Mill. and its essential oil.

Lavandula, commonly known as lavender, is a plant that is a part of the mint family, Lamiaceae, a genus represented by 47 species, which can be found in Europe, northern and eastern Africa, the Mediterranean and southwest Asia, including India, as well as in Australia [20-25]. Lavender is cultivated for several reasons, for example, as an ornamental plant, it is commonly used as culinary and medicinal herb [26], and it is frequently used as a source of essential oils.

Essential oils extracted from Lavandula consist of over 100 components including linalyl acetate (30-55\%), linalool (20-35\%), tannins (5-10\%), and caryophyllene (8\%) as well as other sesquiterpenoids, perillyl alcohols, esters, oxides, ketones, cineole, camphor, $\beta$-ocimene, limonene, caproic acid, and caryophyllene oxide. The relative amounts of those compounds vary considerably depending on the lavender species [27-31].

Lavender oils are used for protection from insects and for their pleasant fragrance. They are commonly used as a component in various cosmetics. There are also numerous papers describing the therapeutic value of lavender essential oils used in aromatherapy [27,28,32-41].

Some Lavandula species are used as herbs. For example, Lavandula angustifolia, which is known as English lavender is preferred as a flavouring food additive, spice, tea, a source of nectar for high quality monofloral honey, and for flavoring ice-cream and sorbets [41-43]. Lavender as generally recognized as safe for human consumption [28]. Lavandula angustifolia Mill. is perhaps the most frequently planted lavender species in Europe, especially north of the Mediterranean area due to its frost-resistance [44]. Therefore, this species was selected for this study to check the functional properties of LPGPA, LPGPN, LPGPM, LPGPC and LPGPO in regard to their effect on the yield and quality of lavender crops as well as the yield of isolated essential oils. Expanding the applicability of the essential oils from lavender in herbal medicine and aromatherapy was also taken into account.

\section{Materials and Methods}

\subsection{Materials}

\subsubsection{Lavandula angustifolia}

Seedlings of Lavandula angustifolia Mill. were purchased via Allegro from Gospodarstwo Rolne, 6, Ptasia Street, 22-300 Krasnystaw (Poland).

\subsubsection{Substrate}

Substrate was composed of medium-size turf fraction Florabalt ${ }^{\circledR}$ Pot Medium-Coarse (Floragard, Oldenburg, Federal Republic of Germany). The medium with a $\mathrm{pH}$ of 5.6, contained $1.2 \mathrm{~g} / \mathrm{L}$ total salts including $210 \mathrm{mg} \mathrm{N} / \mathrm{L}, 120 \mathrm{mg} \mathrm{P}_{2} \mathrm{O}_{5} / \mathrm{L}, 260 \mathrm{mg} \mathrm{K} 2 \mathrm{O} / \mathrm{L}$. It was supplemented with multicomponent PG-Mix 18-10-20 fertilizer $\left(1.20 \mathrm{~kg} / \mathrm{m}^{3}\right.$ ) (Yara, Oslo, Norway) 


\subsubsection{Water}

Tap water from Bolesławiec with a total hardness of $129 \mathrm{mg} / \mathrm{dm}^{3} \mathrm{CaCO}_{3}, \mathrm{pH} 7.1$, conductivity of $334 \mu \mathrm{S} / \mathrm{cm}, \mathrm{Fe}<50 \mu \mathrm{g} / \mathrm{dm}^{3}, \mathrm{Mn}<5 \mu \mathrm{g} / \mathrm{dm}^{3}$ and $6.93 \mathrm{mg} / \mathrm{dm}^{3}$ dissolved oxygen was used as the standard. That water was treated with LPGP for $30 \mathrm{~min}$ in contact with the air following Bialopiotrowicz et al. [8], which resulted in LPGPA. Water treated for the same time with LGPG under nitrogen as described by Chwastowski et al., [7] produced LPGPN. LPGPC [13], LPGPO [9] and LPGPM [12] were prepared following the procedures described in the indicated references. LPGP of $38^{\circ} \mathrm{C}$ was generated at $5 \times 10^{-3} \mathrm{mbar}, 800 \mathrm{~V}, 50 \mathrm{~mA}$ and $10 \mathrm{KHz}$ frequency in a plasmothrone patented by Oszczęda et al. $[1,10]$. The produced water was stored at ambient temperature in $1 \mathrm{~L}$ closed Teflon containers. Every kind of water was used for watering within 3-5 days after it was produced. At $22^{\circ} \mathrm{C}$ the water prepared under molecular oxygen had $\mathrm{pH}=8.37$ whereas all other kinds of water including control, non-treated water had $\mathrm{pH}$ between 6.58 and 6.80 .

\subsubsection{Trays}

QP 15RW multiplates and QP 15RW trays (Herkuplast Kubern GmbH, Ering/Inn, Federal Republic of Germany) were used. Each multiplate consisted of $3 \times 5$ trays. Each tray had $280 \mathrm{~cm}^{3}$ capacity and $1 \mathrm{~m}^{2}$ of greenhouse hosted 880 plants.

\subsection{Methods}

\subsubsection{Lavender Cultivation}

This mono-factorial experiment was carried out from 24 February 2019 (sowing) to 18 May 2019 (harvesting) in a greenhouse at the University of Agriculture in Cracow. The temperature in the greenhouse was set at $22{ }^{\circ} \mathrm{C}$ during the day and $18^{\circ} \mathrm{C}$ at night. Day time was taken as $16 \mathrm{~h}$ from sunrise. The change from the day into the night time regime was controlled by computer. During the $16 \mathrm{~h}$ day, additional illumination was automatically provided by sodium lamps when the natural light intensity decreased below $100 \mathrm{~W} / \mathrm{m}^{2}$. The experiment involved three sets of trays with 24 pots each. Ten seeds of lavender were sown into every pot. In one series of experiments, 2 multiplates hosted 300 plants. In order to eliminate the parietal effect, 60 plants at the edge of the trays were left, and therefore, only 240 plants were harvested. The experiments were run in triplicate, thus a maximum of 720 plants were collected for a given series.

The watering was adjusted according to tensiometer readings (Irrometer model SR $150 \mathrm{~mm}$ ) when the soil water tension was $<-40 \mathrm{kPa}$. The plants were watered by hand to avoid the accidental contact of water with leaves. Initially, plants consumed a total of $3 \mathrm{~L}$ water, that is, $1 \mathrm{~L}$ per replication every 5 days until 24 March 2109. In the subsequent 1-month period, the watering was intensified and the same amount of water was administered to the plants every 3 days. In the final period of the plant breeding, the plants were watered daily with the same amount of water, that is, consumed a total of $40 \mathrm{~mL}$ of each kind of water was consumed each day. Cultivation ended on 18 May 2019 when the plants were collected. The plants were then dried at $105^{\circ} \mathrm{C}$ for $4 \mathrm{~h}$ to determine the dry mass of the crops.

\subsubsection{Ash}

The samples were weighed with a precision of $0.0002 \mathrm{~g}$ and placed in a vessel, which was also weighed at the same precision and this was placed into the front of an oven heated to $815^{\circ} \mathrm{C}$ for $10 \mathrm{~min}$. Then, the vessel with the sample was shifted $(2 \mathrm{~cm} / \mathrm{min})$ into the central region of the chamber. After returning the temperature of the oven returned to $815^{\circ} \mathrm{C}$, the analyzed sample was maintained inside the chamber for a further $25 \mathrm{~min}$. After that time, the sample was left in the open for cooling to room temperature, and then weighed with a precision of $0.0002 \mathrm{~g}$. 


\subsubsection{Fat Content}

Procedure of Zarnowski and Suzuki [45] was followed. The samples were thoroughly crushed in a mortar and weighed $(5 \mathrm{~g} \pm 1 \mathrm{mg})$. They were then blended with anhydrous $\mathrm{Na}_{2} \mathrm{SO}_{4}(5 \mathrm{~g})$ and transferred into an extracting casing, which was filled to less than three quarters of its height. The filled casing was closed with fat-free cotton wool. The $3 \mathrm{~h}$ extraction with $n$-hexane $(200 \mathrm{~mL})$ was carried out in a Soxhlet apparatus equipped with a flask for collecting the extract weighed with a $\pm 1 \mathrm{mg}$ precision. Then, acetone $(2 \mathrm{~mL})$ was added to the flask with the extract cooled to room temperature. On blowing a stream of nitrogen, the solution was slowly heated to remove the acetone and n-hexane. The flask with the extract was heated for $10 \mathrm{~min}$ in a drying box at $103{ }^{\circ} \mathrm{C}$ and then left in a desiccator for cooling to room temperature, followed by weighing. The fat content $(\mathrm{H})(\mathrm{g} / 100 \mathrm{~g}$ or $\%)$ was estimated using Equation (1).

$$
\mathrm{H}=\left[\left(\mathrm{m}_{2}-\mathrm{m}_{1}\right) / \mathrm{m}_{\mathrm{o}}\right] \times 100
$$

where $m_{o}$ is the mass of the sample; $m_{1}$ is the mass of the empty extracting flask; and $m_{2}$ is the mass of the extracting flask with the extract.

\subsubsection{Protein Content}

The Kjeldahl method [46] was applied.

\subsubsection{Carbohydrate Content}

The carbohydrates mass (M) was determined by Equation (2).

$$
\mathrm{M}=100 \mathrm{~g}-\text { mass of fat }- \text { mass of protein }
$$

\subsubsection{Chlorophyll Content}

Procedure by Oren et al. [47] was followed. The lavender leaves (200 mg) were homogenized for $2 \mathrm{~min}$ in a cooled mortar and then homogenized for a further 2 min with the acetone/ammonia $\left(0.05 \mathrm{~mol} / \mathrm{dm}^{3}\right)$ in an $8: 2$ blend $\left(5 \mathrm{~cm}^{3}\right)$ cooled to $0-5^{\circ} \mathrm{C}$. The extraction was continued for 2 more minutes by the addition of a $5 \mathrm{~cm}^{3}$ of the extracting acetone/ammonia blend. The resulting suspension of the well-crushed sample was transferred into a $25 \mathrm{~cm}^{3}$ measuring cylinder, the mortar was washed with an extracting blend $\left(10 \mathrm{~cm}^{3}\right)$ and the wash was combined with the extract. The extract was then centrifuged for $10 \mathrm{~min}$ at $5000 \mathrm{rpm}$, and decanted. The volume of the extract was increased to $25 \mathrm{~cm}^{3}$ by adding the extracting blend. The experiments were run in triplicate.

The absorbance (A) of the resulting extract was taken at 470, 647 and $664 \mathrm{~nm}$. The content of chlorophylls a and b in $\mathrm{mg} / \mathrm{g}$ was estimated from Equations (3) and (4), respectively.

$$
\text { chl. } \mathrm{a}=25 \times \mathrm{a} / \mathrm{m}
$$

where $\mathrm{a}=11.78 \times \mathrm{A}_{664}-2.29 \times \mathrm{A}_{647}$ and $\mathrm{m}$ denotes the weight $(\mathrm{mg})$ of the fresh plant material

$$
\text { chl.b }=25 \times \mathrm{b} / \mathrm{m}
$$

where $\mathrm{b}=20.05 \times \mathrm{A}_{647}-4.77 \times \mathrm{A}_{664}$ and $\mathrm{m}$ denotes the weight $(\mathrm{mg})$ of the fresh plant material.

\subsubsection{Carotenoids Content}

The procedure by Kopec et al. [48] was followed. The carotenoids content ( $\beta$-carotene and xanthophyll) was calculated by Equation (5).

$$
\operatorname{car}=25 \times c / 229 \mathrm{~m}
$$

where $\mathrm{c}=1000 \mathrm{~A}_{470}-3.27 \mathrm{a}-104 \mathrm{~b}$ and $\mathrm{m}$ denotes the weight $(\mathrm{mg})$ of the fresh plant material. 


\subsubsection{Determination of Ascorbic Acid}

A sample of the dried plant $(1 \mathrm{~g})$ was crushed in a mortar with $50 \mathrm{~cm}^{3}$ distilled water and $5 \mathrm{~cm}^{3}$ of a $0.1 \mathrm{M}$ aqueous solution into which potato starch was added. This solution was titrated with an iodine solution according to Al Majidi and Al Qubury [49]. The estimations were triplicated.

\subsubsection{Analyses for Cations}

Samples were mineralized in a microwave oven (MarsXpress CEM Company, Matthews, NC USA). Samples $(0.5 \mathrm{~g})$ were digested with nitric acid, $65 \%$ of analytical grade $\left(10 \mathrm{~cm}^{3}\right)$. The metal content was determined by atomic absorption spectrometry with an electrothermal device (AA Varian 240 instrument). A palladium standard solution $\left(1000 \mathrm{mg} / \mathrm{dm}^{3}\right)$ was used as a modifier.

\subsubsection{Preparation of Extracts}

Extracts were prepared by grinding the plant material in a mortar $(20 \mathrm{~g})$ with $96 \%$ ethanol $\left(100 \mathrm{~cm}^{3}\right)$ for $30 \mathrm{~min}$.

\subsubsection{Separation of Essential Oils}

Samples of the plant dried at $35^{\circ} \mathrm{C}$ to a constant weight $(1 \mathrm{~g})$ were steam distilled in a Deryng apparatus with closed water circulation. The collected oils were transferred to a closed vial and stored in dry ice until analyzed. Analysis was performed within three days [50].

\subsubsection{Gas Chromatographic Analyses}

Sample $(5 \mu \mathrm{L})$ was transferred to a closed chromatographic vial and evaporated on a heating plate. Using a gas-tight syringe, gaseous sample $(10 \mu \mathrm{L})$ was analyzed using a Bruker 436-GC gas chromatograph coupled with a Bruker SCION SQ (single quadruple, electron ionization) mass spectrometer (Durham, UK). The estimations were duplicated.

The instrument was equipped with a BR-5ms; $0.25 \mathrm{~nm} \times 30 \mathrm{~m}, \mathrm{df}=0.25 \mu \mathrm{m}$. The column operated at the following temperature program: $50{ }^{\circ} \mathrm{C}(2 \mathrm{~min})$ at a temperature rate increase of $10^{\circ} \mathrm{C} / \mathrm{min}$ up to $170{ }^{\circ} \mathrm{C}(0 \mathrm{~min})$, then at $25^{\circ} \mathrm{C}$ up to $280^{\circ} \mathrm{C}(5 \mathrm{~min})$.

The dispenser, transfer line and source temperature was 300,280 and $200^{\circ} \mathrm{C}$, respectively. Sample separation was set as 1:20, helium was used as the carrier gas. The flow of the mobile phase was $1.0 \mathrm{~mL} / \mathrm{min}$, and the ionization energy was $70 \mathrm{keV}$. Scanning was performed in the 50-500 m/z range.

Chromatographic signals were identified by comparison with mass spectra available in the NIST 11 library. Areas under particular chromatographic peaks were calculated with a computer programme installed in the chromatograph.

\subsection{Statistics}

The results were subjected to statistical interpretation, mean values and standard errors were calculated, and the significance of the variables was determined. Statistically significant differences between means $(p<0.05)$ were evaluated using one-way analysis of variance (ANOVA) with a post hoc multiply Duncan's range test [51]. Moreover, the Pearson product-moment correlation coefficients between analyzed variables were calculated. The significance level for the correlation coefficient was $p=0.05$, and the number of pairs for the calculations was $\mathrm{N}=216$. All statistical analyses were calculated using Statistica 13.3 software (Tibco Software Inc., Palo Alto, CA, USA).

\section{Results and Discussion}

The results were all clearly associated with the structural properties of a particular LPGP. Only LPGPA and LPGPN contained small structural units of aqueous clathrates hosting excited molecules of oxygen and nitrogen, respectively. The size of the clathrates facilitated their permeation across cell membranes. Hence, both types of water became particularly good vectors for 
hosted molecules, which can influence the biosynthesis of various components of the lavender. LPGPA enriched the interior of cells in molecular oxygen. Excited, singlet oxygen molecules liberated inside the cells released energy on returning to the normal triplet state. That energy can influence the course of cellular bioprocesses not necessarily resulting from the oxidation. LPGPN directed into the cells excited forms of molecular nitrogen, which were developed by the treatment of water under nitrogen. Thus, nitrogen molecules in their excited, free radical forms can contribute to the biosynthesis of nitrogen-containing compounds, while simultaneously affecting processes related to the oxidation.

LPGPC, LPGPO and LPGPM do not contain clathrates. Their macrostructures were stable depending on the proportion of involved hydrogen bonding configurations and the content of niches available in these macrostructures. The macrostructure of LPGPM was relatively stable and hosted methane molecules in its niches. In contrast to LPGPM, LPGPO carried molecular oxygen in the triplet state in its niches. The oxygen molecules also participated in building the macrostructure. Thus, LPGPO was clearly different from the remaining types of water with regard to its potential oxidative properties. LPGPC was built mainly of surface tetrahedral and deformed tetrahedral structural units. The niches of its macrostructure incorporated O-free radicals of triplet carbon dioxide.

Plants produce a vast and diverse assortment of organic compounds, the great majority of which do not participate directly in their growth and development. These substances are referred to as secondary metabolites and their functions are elucidated with increasing frequency as they have great utility as dyes, polymers, fibre, glues, oils, waxes, flavouring agents, perfumes and drugs. Based on their biosynthetic origins, natural plant products can be divided into three major groups: terpenoids, alkaloids, and phenylpropanoids with allied phenolic compounds. There are numerous and different biochemical agents, for example, the terpenoids include over 25,000 secondary compounds and they are derived from the five-carbon precursor isopentenyl diphosphate (IPP). The fundamental feature of the organization of terpenoid metabolism exists at the subcellular level.

The biosynthetic pathways for the formation of the basic precursor IPP differ markedly in these compartments, with the classic acetate/mevalonate pathway being active in the cytosol and ER and the glyceraldehydephosphate/pyruvate pathway operating in the plastid. Mitochondria, the third actor in biosynthesis, may generate the ubiquinone phenyl group via the acetate/mevalonate pathway. The complicated metabolism scheme indicates that the regulation of terpenoid synthesis may occur in different ways, e.g., substrate and the transport of intermediates to the cytosol, ER, enzymatic regulation and even gene expression regulation [52].

All processes that lead to those products can be influenced by particular types of water. The data shown in Tables 1 and 2 characterize the crops of L. angustofolia Mill. watered with non-treated tap water and water treated with glow plasma in the air, (LPGPA) under nitrogen (LPGPN), carbon dioxide (LPGPC), methane (LPGPM) and molecular oxygen (LPGPO).

Table 1. Characteristics crops of L. angustofolia Mill. Results of watering plants with non-treated tap water and water treated with glow plasma in the air, (LPGPA) under nitrogen (LPGPN), carbon dioxide (LPGPC), methane (LPGPM) and molecular oxygen (LPGPO).

\begin{tabular}{|c|c|c|c|c|c|c|c|}
\hline \multirow{2}{*}{ Water } & \multirow{2}{*}{$\begin{array}{c}\text { Yield } \\
\text { [g] }\end{array}$} & \multirow{2}{*}{$\begin{array}{c}\text { Dry } \\
\text { mass [g] }\end{array}$} & \multirow{2}{*}{$\begin{array}{l}\text { Ash } \\
{[\%]}\end{array}$} & \multicolumn{4}{|c|}{ Selected Ion Content [mg/g Dry Mas] } \\
\hline & & & & $\mathrm{Na}^{+}$ & $\mathrm{K}^{+}$ & $\mathrm{Ca}^{2+}$ & $\mathrm{Mg}^{2+}$ \\
\hline Control & 184 & 135 & $6.63 \pm 0.02$ & $0.233 \pm 0.002$ & $14.253 \pm 0.007$ & $3.192 \pm 0.004$ & $1.373 \pm 0.002$ \\
\hline LPGPA & 195 & 136 & $7.02 \pm 0.04$ & $0.265 \pm 0.002$ & $14.685 \pm 0.005$ & $3.256 \pm 0.002$ & $1.421 \pm 0.001$ \\
\hline LPGPN & 197 & 142 & $7.23 \pm 0.03$ & $0.267 \pm 0.004$ & $14.562 \pm 0.003$ & $3.251 \pm 0.003$ & $1.488 \pm 0.003$ \\
\hline LPGPC & 186 & 134 & $6.83 \pm 0.02$ & $0.262 \pm 0.003$ & $14.685 \pm 0.005$ & $3.249 \pm 0.002$ & $1.288 \pm 0.003$ \\
\hline LPGPM & 190 & 133 & $6.68 \pm 0.03$ & $0.261 \pm 0.005$ & $14.623 \pm 0.002$ & $3.255 \pm 0.001$ & $1.379 \pm 0.003$ \\
\hline LPGPO & 184 & 133 & $6.23 \pm 0.03$ & $0.268 \pm 0.001$ & $14.522 \pm 0.004$ & $3.258 \pm 0.004$ & $1.376 \pm 0.003$ \\
\hline
\end{tabular}

Only LPGPN produced increases in the crop yield with regard to dry mass and ash content, which could be the result of enhanced uptake of minerals. The formation of proteins could facilitate 
that uptake by coordination of the ions. Indeed, watering with LPGPN provided the highest level of chlorophyll. Plants watered with LPGPN showed the highest content of proteins, which confirmed the involvement of excited forms of molecular nitrogen in the synthesis of protein. The enhanced content of carbohydrates in plants watered with LPGPC suggested that excited forms of carbon dioxide participated in the biosynthesis of carbohydrates. LPGPO clearly reduced the yield of crops by inhibiting uptake of mineral components. The content of the treated water had a minor influence on the synthesis of chlorophylls, carotenoids and ascorbic acid.

As shown in Table 3, plants watered with LPGPA and LPGPN showed a two-fold increase in the yield of essential oil, whereas watering with LPGPC and LPGPO increased the yield of essential oil by $50 \%$. Only LPGPM did not influence the yield of essential oil. However, watering plants with LPGPM produced an essential oil with a very specific composition.

Thirty-eight components were characterised in essential oil from Lavandula angustifolia watered with non-treated tap water. Coumarin and herniarin, a derivative of coumarin were the main components (Table 3). Biosynthesis of both those components in lavender was recognized by Brown [53]. Additionally, camphene, 3-carene, D-limonene, $\beta$-phellandrene, eucalyptol, camphor, endo-borneol, cryptone, $\beta$-elemene, caryophyllene, $\gamma$-cadinene and $\tau$-cadinol were found in this essential oil, each in amounts exceeding $1 \%$ of the total essential oil amount (Table 3).

Essential oil from the plants watered with LPGPA was found to be composed of 41 components. These were dominated by eucalyptol, endo-borneol and herniarin whereas only traces of coumarin were found. Only the application of LPGPA provided a trace of $\alpha$-pinene, 3-octanone, $\gamma$-terpinene, considerable amounts of $\beta$-ocimene and endo-borneol. Watering with LPGPA was beneficial for the biosynthesis of essential oil that was rich in $\beta$-phellandrene, cryptone, trans-piperitol, linallyl acetate and $\alpha$-santalene. Watering L. angustifolia with LPGPN resulted in an essential oil with a depleted number of components. Its 23 components were dominated by herniarin and included $\sigma$-cadinene and geranyl propionate. There were also relatively high amounts of sabinene and D-limonene. Essential oil from lavender watered with LPGPC was composed of only 21 components. Again, these were dominated by coumarin although considerable amounts of herniarin, eucalyptol, berberone and endo-borneol were also identified. In fact, watering L. angustofolia with LPGPC water produced the highest amount of berbenol of all the water tested. Watering lavender with LPGPO increased the number of components in its essential oil to 33. Coumarin and herniarin were the main components and eucalyptol and 1-octenyl-3-ol were also found in fairly considerable amounts. Watering with LPGPO resulted in the highest yield of the latter component compared to watering with the other types of water. The use of LPGPM produced essential oil with 29 components. LPGPM water completely blocked the biosynthesis of coumarin but only slightly affected the formation of herniarin and it promoted the biosynthesis of camphor as well as considerable amounts of $\gamma$-cadinene and $\tau$-cadinol.

The results shown in Table 3 suggest that, for instance, essential oil from lavender watered with LPGPO could be beneficial when the biological and physiological properties of dihydrosabinene (also known as thujone) [54] are required. In cases where the therapeutic properties of pinenes [55] could be utilized, the essential oil from lavender watered with LPGPC would be recommended. Due to its high content of $\beta$-ocimene, essential oil from plants watered with LPGPA would be most suitable when the antifungal, antiviral, and anti-inflammatory properties of the preparation are required [56]. Because of its relatively high content of artemisole, essential oil from plants watered with LPGPO could be useful for treating various skin diseases [53]. Essential oil from plants watered with LPGPO contain a high level of piperitol, which is suitable for controlling allergic responses, and curing sexual dysfunction and anorexia [57-60]. Essential oil from lavender watered with LPGPN might be recommended when juniper aroma [60] and the biological properties of herniarin are desired (for example, for use in dyspepsia and inadequate bile secretion, and also as a sedative in nervous intestinal disorders) [61]. 
Table 2. Influence of watering plants with non-treated tap water and water treated with glow plasma in the air, (LPGPA) under nitrogen (LPGPN), carbon dioxide (LPGPC), methane (LPGPM) and molecular oxygen (LPGPO) on the yield of chlorophylls a and b, carotenoids and ascorbic acid.

\begin{tabular}{|c|c|c|c|c|c|c|c|c|}
\hline \multicolumn{9}{|c|}{ Component Content [g/100g Dry Mass] } \\
\hline \multirow{2}{*}{ Water } & \multicolumn{3}{|c|}{ Chlorophyll } & \multirow{2}{*}{ Carotenoids } & \multirow{2}{*}{ Ascorbic Acid } & \multirow{2}{*}{ Fat } & \multirow{2}{*}{ Protein } & \multirow{2}{*}{ Carbohydrate } \\
\hline & $\mathbf{a}$ & $\mathbf{b}$ & Total & & & & & \\
\hline Control & $1.352 \pm 0.023$ & $0.235 \pm 0.013$ & $1.587 \pm 0.018$ & $0.315 \pm 0.003$ & $0.113 \pm 0.005$ & $0.63 \pm 0.01$ & $1.87 \pm 0.01$ & $97.50 \pm 0.01$ \\
\hline LPGPA & $1.421 \pm 0.018$ & $0.293 \pm 0.014$ & $1.714 \pm 0.016$ & $0.329 \pm 0.004$ & $0.118 \pm 0.003$ & $0.52 \pm 0.02$ & $1.92 \pm 0.02$ & $97.56 \pm 0.02$ \\
\hline LPGPN & $1.472 \pm 0.021$ & $0.308 \pm 0.012$ & $1.780 \pm 0.016$ & $0.337 \pm 0.004$ & $0.117 \pm 0.004$ & $0.53 \pm 0.03$ & $2.21 \pm 0.01$ & $97.26 \pm 0.02$ \\
\hline LPGPC & $1.363 \pm 0.011$ & $0.241 \pm 0.013$ & $1.604 \pm 0.012$ & $0.316 \pm 0.003$ & $0.123 \pm 0.005$ & $0.51 \pm 0.01$ & $1.63 \pm 0.04$ & $97.86 \pm 0.02$ \\
\hline LPGPM & $1.342 \pm 0.018$ & $0.218 \pm 0.011$ & $1.560 \pm 0.015$ & $0.318 \pm 0.002$ & $0.119 \pm 0.002$ & $0.62 \pm 0.01$ & $1.83 \pm 0.02$ & $97.55 \pm 0.02$ \\
\hline LPGPO & $1.292 \pm 0.016$ & $0.246 \pm 0.009$ & $1.538 \pm 0.013$ & $0.309 \pm 0.004$ & $0.109 \pm 0.003$ & $0.58 \pm 0.02$ & $1.78 \pm 0.02$ & $97.64 . \pm 0.02$ \\
\hline
\end{tabular}

Table 3. Chromatographic characteristics of essential oils isolated from Lavandula angustifolia watered with water treated with glow plasma in contact with the air, oxygen-free nitrogen, carbon dioxide, molecular oxygen and methane.

\begin{tabular}{|c|c|c|c|c|c|c|c|c|}
\hline \multirow[b]{2}{*}{ Peak Position in Chromatogram } & \multirow[b]{2}{*}{ Retention Time [min] } & \multirow[b]{2}{*}{ Component $^{a}$} & \multicolumn{6}{|c|}{ Water Treated under } \\
\hline & & & Non-Treated & Air & $\mathbf{N}_{2}$ & $\mathrm{CO}_{2}$ & $\mathrm{O}_{2}$ & $\mathrm{CH}_{4}$ \\
\hline 2. & 7.27 & $\alpha$-Pinene & - & 0.04 & - & - & - & - \\
\hline 3. & 7.68 & Camphene & 1.25 & 0.1 & 4.96 & 0.09 & - & 1.35 \\
\hline 4. & 7.77 & Dihydrosabinene & - & - & - & - & 2.36 & - \\
\hline 5. & 8.22 & Sabinene & 0.28 & 0.02 & 8.25 & - & 0.28 & 0.28 \\
\hline 6. & 8.36 & 1-Octen-3-ol & - & 1.36 & - & - & 6.58 & - \\
\hline 7. & 8.38 & $(-)$ - $\beta$-Pinene & 0.59 & 0.73 & - & 6.21 & - & - \\
\hline 8. & 8.49 & 3-Octanone & - & 0.36 & - & - & - & - \\
\hline 9. & 8.60 & $\beta$-Pinene & 0.58 & 1.07 & - & 0.58 & 3.65 & 0.58 \\
\hline 12. & 9.05 & $\alpha$-Phellandrene & 0.28 & 0.53 & - & - & - & - \\
\hline 13. & 9.13 & 3-Carene & 3.78 & 5.56 & 6.56 & 3.78 & - & 3.78 \\
\hline 15. & 9.37 & p-Cymene & 0.48 & 0.4 & 0.01 & - & - & - \\
\hline 16. & 9.51 & o-Cymene & 0.98 & 0.81 & - & - & - & 0.98 \\
\hline 17. & 9.63 & D-Limonene & 2.12 & 2.79 & 8.92 & 1.11 & 3.12 & 2.12 \\
\hline 18. & 9.70 & $\beta$-Phellandrene & 3.86 & 7.16 & - & 2.68 & 2.86 & - \\
\hline 19. & 9.71 & Eucalyptol & 4.31 & 21.68 & - & 8.75 & 9.52 & 4.31 \\
\hline
\end{tabular}


Table 3. Cont.

\begin{tabular}{|c|c|c|c|c|c|c|c|c|}
\hline \multirow[b]{2}{*}{ Peak Position in Chromatogram } & \multirow[b]{2}{*}{ Retention Time [min] } & \multirow[b]{2}{*}{ Component ${ }^{a}$} & \multicolumn{6}{|c|}{ Water Treated under } \\
\hline & & & Non-Treated & Air & $\mathbf{N}_{2}$ & $\mathrm{CO}_{2}$ & $\mathrm{O}_{2}$ & $\mathrm{CH}_{4}$ \\
\hline 20. & 9.77 & trans- $\beta$-Ocimene & - & - & - & - & 1.62 & - \\
\hline 21. & 10.04 & $\beta$-Ocimene & - & 4.2 & - & - & - & - \\
\hline 22. & 10.37 & $\gamma$-Terpinene & - & 0.06 & - & - & - & - \\
\hline 23. & 10.67 & cis- $\beta$-Terpineol & 0.31 & - & - & - & 0.31 & - \\
\hline 25. & 11.09 & Terpinolene & 0.15 & 0.28 & - & - & 0.68 & 0.15 \\
\hline 27. & 11.40 & Linalool & 0.63 & - & - & 3.68 & 0.41 & - \\
\hline 30. & 12.11 & Neo-allo-ocimene & - & - & - & - & 0.36 & - \\
\hline 31. & 12.24 & Artemiseol & - & 0.35 & - & - & 3.51 & - \\
\hline 34. & 12.63 & Camphor & 6.42 & 0.84 & 3.68 & - & 0.23 & 28.52 \\
\hline 36. & 12.99 & Lavandulol & 0.26 & 0.22 & - & 6.39 & 4.25 & 0.2 \\
\hline 40. & 13.24 & endo-Borneol dup-1 & 8.00 & 10.27 & 4.28 & 8.06 & 1.65 & 12.68 \\
\hline 43. & 13.41 & p-Cymen-8-ol & 0.35 & 0.28 & 0.3 & 0.42 & - & 0.45 \\
\hline 45. & 13.58 & Cryptone & 1.79 & 1.88 & - & - & 1.79 & 1.79 \\
\hline 46. & 13.80 & $\alpha$-Terpineol & 0.98 & 0.4 & 0.27 & - & - & 0.22 \\
\hline 49. & 13.99 & endo-Borneol & 0.13 & 0.11 & - & 0.13 & - & 0.13 \\
\hline 52. & 14.12 & trans-Piperitol & - & 3.15 & - & - & 3.26 & - \\
\hline 55. & 14.93 & Cuminal & 0.5 & 0.4 & 0.45 & - & - & 0.5 \\
\hline 58. & 15.08 & Linalyl acetate & 0.3 & 1.41 & 0.29 & - & 0.16 & 0.16 \\
\hline 62. & 15.81 & Carveol & 0.38 & 0.85 & 0.38 & - & 0.28 & 0.48 \\
\hline 63. & 15.82 & Lavandulol acetate & - & - & - & - & 1.25 & - \\
\hline 64. & 15.92 & Bornyl acetate & 0.18 & 0.35 & 0.18 & - & 0.18 & 0.18 \\
\hline 67. & 16.07 & p-Cymen-7-ol & 0.23 & 0.24 & 0.23 & 2.98 & - & - \\
\hline 69. & 16.46 & Berbenone & 0.68 & 0.61 & - & 8.56 & 0.7 & 0.62 \\
\hline 77. & 17.96 & Geranyl acetate & - & 1.54 & - & - & - & - \\
\hline 78. & 18.02 & $\beta$-Elemene & 6.54 & - & - & - & - & - \\
\hline 81. & 18.91 & $\alpha$-Santalene & 0.63 & 5.82 & 0.63 & 0.63 & 0.71 & 0.63 \\
\hline 82. & 18.97 & Caryophyllene & 1.68 & 0.53 & 0.68 & - & 0.24 & 0.68 \\
\hline 84. & 19.14 & $\alpha$-Bergamotene dup-1 & 0.09 & 0.28 & - & 0.09 & 0.09 & 3.95 \\
\hline 85. & 19.22 & Coumarin & 27.82 & 0.25 & 0.21 & 28.69 & 25.63 & - \\
\hline 87. & 19.59 & Geranyl propionate & 0.36 & - & 11.65 & 0.15 & 0.21 & 0.14 \\
\hline 88. & 19.83 & Germacrene D & 0.63 & - & 0.06 & 0.1 & 0.06 & 0.06 \\
\hline
\end{tabular}


Table 3. Cont.

\begin{tabular}{|c|c|c|c|c|c|c|c|c|}
\hline \multirow[b]{2}{*}{ Peak Position in Chromatogram } & \multirow[b]{2}{*}{ Retention Time [min] } & \multirow[b]{2}{*}{ Component ${ }^{a}$} & \multicolumn{6}{|c|}{ Water Treated under } \\
\hline & & & Non-Treated & Air & $\mathbf{N}_{2}$ & $\mathrm{CO}_{2}$ & $\mathrm{O}_{2}$ & $\mathrm{CH}_{4}$ \\
\hline 92. & 20.16 & $\gamma$-Cadinene & 2.22 & - & - & - & 2.16 & 9.25 \\
\hline 93. & 20.20 & $\sigma$-Cadinene & - & 2.36 & 13.76 & - & - & - \\
\hline 94. & 20.74 & 4-epi-Cubenol & - & - & 0.32 & - & - & - \\
\hline 95. & 20.80 & Caryophyllene oxide & 0.99 & 0.33 & - & - & 0.99 & 0.99 \\
\hline 97. & 21.21 & $\tau$-Cadinol & 5.1 & 6.3 & 3.25 & 5.27 & 5.65 & 9.85 \\
\hline \multirow{3}{*}{$\begin{array}{l}\text { Tota } \\
\text { Yield of es }\end{array}$} & 21.73 & Herniarin & 14.14 & 14.08 & 30.68 & 11.65 & 15.25 & 14.97 \\
\hline & umber of components & & 38 & 41 & 23 & 21 & 33 & 29 \\
\hline & tial oil (mL/100 g dry mass) & & 0.2 & 0.4 & 0.4 & 0.3 & 0.3 & 0.2 \\
\hline
\end{tabular}

a Sum of amounts $(\mathrm{mg})$ of particular components in particular columns constitute $100 \%$ content of the given essential oil. 
The majority of compounds listed in Table 3 are terpenoids and alkaloids. The effect of LPGPN on the concentration of camphene, sabinene, D-limone and geranyl propionate was very significant. The enhanced biosynthesis of the mentioned compounds in the presence of free radical nitrogen (LPGPN) might be explained in terms of the IPP facilitated transport by the LPGPN.

LPGPN water might influence an exchange of IPP between different compartments. In the case of LPGPA and LPGPO, the effect on the biosynthesis of terpenoids may rely on an increase in the modification of its basic parent skeleton by terpenoid synthetases. The modification mostly involves oxidation, reduction, isomerization and conjugation reaction, which impart functional properties. Most hydroxylation or epoxidation reactions involve the introduction of oxygen atoms into terpenoid skeleton. Cytochrome P-450 oxidases are responsible for the oxygen built-in reactions. As mentioned above, the LPGA and LPGO could promote the use of oxygen closed in the clathrates. Moreover, the excited singlet state of oxygen dominates in the clathrates and its deactivation into triplet states might increase the activity of cytochrome P-450 oxidases.

At the same time, it is likely that P-450 acts as an acceptor of free electrons. An alternative explanation is related to the additional portion of nitrogen that is carried in the supplied water. The reduction in excited forms of $\mathrm{N}_{2}$ by bacteria in the plant rhizosphere could be responsible for the production of organic nitrogen compounds, which involves the higher biosynthesis of appropriate enzymes needed for conversion of IPP into monoterpenes [52,62-64].

\section{Conclusions}

All of the glow plasma treated water used in this study resulted in a slight difference in the yield and quality of lavender crops. Only plants watered with water treated under nitrogen produced a significantly higher crop yield and the crop was also richer in protein.

The most useful results of this study on watering lavender with particular types of treated water was the effect on the yield and composition of isolated essential oils, as an understanding of the composition of particular essential oils may be beneficial in a number of applications. For instance, essential oil from lavender watered with LPGPO could be beneficial when the biological and physiological properties of dihydrosabinene (thujone) are required. When the therapeutic properties of pinenes are required, essential oil from lavender watered with LPGPC could be recommended. For antifungal, antiviral, and anti-inflammatory applications, essential oil from the plants watered with LPGPA would be most suitable due to its high content of $\beta$-ocimene. The relatively high content of artemisole in the essential oil from the plants watered with LPGPO could be beneficial for treating various skin diseases. Essential oil from the plants watered with LPGPO contain a high level of piperitol and would be suitable for controlling allergic responses, and curing sexual dysfunction and anorexia. Finally, essential oil from lavender watered with LPGPN could be recommended whenever juniper aroma and the biological properties of herniarin are required for dyspepsia and inadequate bile secretion or as a sedative in nervous intestinal disorders.,

Author Contributions: K.C. run lavender cultivation, W.C. run determination of fat, protein, carbohydrate and chlorophyll content, H.K. run analysis of crop yield, dry mass, ash, T.G. separation of essential oils, Z.O. equipped a research team in nanowater, P.T. invented the project, coordinated study and designed the text of this report. All authors jointly participated in interpretation of all data and in writing report. All authors have read and agreed to the published version of the manuscript.

Funding: This research did not receive any specific grant from funding agencies in the public, commercial, or not-for-profit sectors.

Conflicts of Interest: The authors declare no conflict of interest. 


\section{References}

1. Oszczeda, Z.; Elkin, I.; Strek, W. Equipment for Treatment of Water with Plasma. Polish Patent PL 216025 B1, 28 February 2014.

2. Donsbach, K.W.; Cazares, R. Process for Making Highly Oxygenated Drinking Water and Drinking Water Made by the Process. U.S. Patent 5587191A, 24 December 1996.

3. Zelenak, Z.M.; Berzsenyi, L.; Abramo, F. Oxygen Enriched Liquids, Method and Apparatus for Making, and Applications Thereof. U.S. Patent 581422A, 29 September 1998.

4. DeWald, J.J. Method and Apparatus for Adding Oxygen to Drinking Water. U.S. Patent 69361179B2, 30 August 2005.

5. Compagnie Gervais Danone. Method for Enriching Water with Oxygen by an Electrolytic Process, Oxygen Enriched Water or Beverage and Uses Thereof. U.S. Patent 8,709,231, 19 December 2008.

6. Messer Americas, FARMOX. Drop-in Oxygenation Apparatus. New, Easy-to-Deploy, Highly Efficient Solution for Oxygenation of Water. Available online: https://cdn2.hubspot.net/hubfs/189660/Messer\%20US\% 20Website_2019/Resources/MESS-3024_FARMOX_Dropln_datasheet.pdf (accessed on 25 June 2020).

7. Chwastowski, J.; Ciesielska, K.; Ciesielski, W.; Khachatryan, K.; Kołoczek, H.; Kulawik, D.; Oszczęda, P.; Tomasik, P.; Witczak, M. Structure and physicochemical properties of water treated under nitrogen with low-temperature glow plasma. Water 2020, 12, 131. [CrossRef]

8. Białopiotrowicz, T.; Ciesielski, W.; Domański, J.; Doskocz, M.; Fiedorowicz, M.; Grąż, K.; Khachatryan, K.; Kołoczek, H.; Kozak, A.; Oszczęda, Z.; et al. Structure and physicochemical properties of water treated with low-temperature low-frequency plasma. Curr. Phys. Chem. 2016, 6, 312-320. [CrossRef]

9. Chwastowski, J.; Ciesielski, W.; Khachatryan, K.; Kołoczek, H.; Kulawik, D.; Oszczęda, Z.; Soroka, J.A.; Tomasik, P.; Witczak, M. Water of increased content of molecular oxygen. Water 2020, 12, 02488. [CrossRef]

10. Reszke, E.; Yelkin, I.; Oszczęda, Z. Plasming Lamp with Power Supply. Polish Patent PL 227530 B1, 26 October 2017.

11. Ciesielska, A.; Ciesielski, W.; Kołoczek, H.; Kulawik, D.; Kończyk, J.; Oszczęda, Z.; Tomasik, P. Structure and some physicochemical and functional properties of water treated under ammonia with low-temperature low-pressure glow plasma of low-frequency. Glob. J. Chem. 2020, 18, 1-12. [CrossRef]

12. Ciesielska, A.; Ciesielski, W.; Khachatryan, K.; Kołoczek, H.; Kulawik, D.; Oszczeda, Z.; Soroka, J.A.; Tomasik, P. Structure and physicochemical properties of water treated under methane with low-temperature glow plasma of low frequency. Water 2020, 12, 1638. [CrossRef]

13. Ciesielska, A.; Ciesielski, W.; Khachatryan, K.; Kołoczek, H.; Kulawik, D.; Oszczęda, Z.; Soroka, J.A.; Tomasik, P. Structure and physicochemical properties of water treated under carbon dioxide with low-temperature glow plasma of low frequency. Water 2020, 12, 1920. [CrossRef]

14. Jaworska, M.; Oszczęda, Z.; Tomasik, P. Water treated with low-temperature, low-pressure, low-frequency glow plasma as a stimulant of pathogenicity and reproduction of biopesticides Part I. Entomopathogenic fungi. Pol. J. Nat. Sci. 2018, 33, 561-568.

15. Pater, A.; Zdaniewicz, M.; Satora, P.; Khachatryan, G.; Oszczeda, Z. Application of water treated with low-temperature low-pressure glow plasma for quality improvement of barley and malt. Biomolecules 2020, 10, 267. [CrossRef]

16. Murawski, M.; Schwarz, T.; Grygier, J.; Patkowski, K.; Oszczęda, Z.; Jelkin, I.; Kosiek, A.; Gruszecki, T.M.; Szymanowska, A.; Skrzypek, T.; et al. The utility of nanowater for ram semen cryopreservation. Exp. Biol. Med. 2014, 240, 611-617. [CrossRef]

17. Szymanowicz, J.; Schwarz, T.; Murawski, M.; Małopolska, M.; Oszczęda, Z.; Tuz, R.; Nowicki, J.; Bartlewski, P.M. Storage, of bear semen at $16-18{ }^{\circ} \mathrm{C}$ in the long term commercial extender prepared with deionized water or nanowater. Anim. Reprod. 2019, 16, 1-7. [CrossRef]

18. Wolski, K.; Talar-Krasa, M.; Leshchenko, A.; Dradrach, A.; Adamczewska-Sowińska, K.; Oszczęda, Z. Application of nanowater and biopreparations in agriculture. Pr. Nauk. Politechnika Opolska. Ser. Stud. Monogr. 2014, 404, 265-271. (In Polish) 
19. Pisulewska, E.; Ciesielski, W.; Jackowska, M.; Gąstoł, M.; Oszczęda, Z.; Tomasik, P. Effect of water treated with low-pressure, low-temperature glow plasma of low frequency on planted peppermint (Mentha piperita), EJPAU, Electron. J. Pol. Agric. Univ. Ser. Biotechnol. 2018, 21, 1.

20. Upson, T.; Andrews, S. The Genus Lavandula; Royal Botanic Gardens, Kew; Timber Press: Portland, OR, USA, 2004; ISBN 9780881926422.

21. Bailey, L.H. Manual of Cultivated Plants; MacMillan Publishing Company: New York, NY, USA, 1949.

22. Lis-Balchin, M. Lavender: The Genus Lavandula; Taylor and Francis: London, UK, 2002; ISBN 9780203216521.

23. Mabberley, D.J. Mabberley's Plant-Book; Cambridge University Press: Cambridge, UK, 2017; ISBN 978-1-107-11502-6.

24. Royal Botanic Gardens, World Checklist of Selected Plant Families: Royal Botanic Gardens, Kew Sciences. 2020. Available online: https://wcsp.science.kew.org/prepareChecklist.do; jsessionid=7177C3D5E74073EA2B8DFF2EC93277EC.kppapp06-csp?checklist=selected_families\% 40\%40233200820201002611kew.org (accessed on 20 August 2020).

25. Csurches, S.; Edwards, R. National Weeds Program Potential Environmental Weeds in Australia, Candidate Species for Preventative Control; Queensland Department of Natural Resources: Mackay, Australia, 1998; ISBN 0-642-21409-3.

26. Blankespoor, J. Lavender's Medicinal and Aromatherapyuses and Lavender Truffles; Chestnut School of Herbal Medicine: Weaverville, NC, USA, 2012.

27. Plant finder-Plectranthus Mona Lavender. Missouri Botanical Garden: St. Louis, MO, USA, 2020. Available online: www.missouribotanicalgarden.org (accessed on 21 August 2020).

28. Lavender. Drugs.com. Available online: https://www.drugs.com/npp/lavender.html (accessed on 1 November 2018).

29. Lavender. Drugs and Lactation Database (LactMed), National Library of Medicine, US National Institutes of Health, 3 December 2018. Available online: https://www.ncbi.nlm.nih.gov/books/NBK501865/ (accessed on 20 August 2020).

30. Umezu, T.; Nagano, K.; Ito, H.; Kosakai, K.; Sakaniwa, M.; Morita, M. Anticonflict effects of lavender oil and identification of its active constituents. Pharm. Biochem. Behavior 2006, 85, 713-721. [CrossRef] [PubMed]

31. Griffiths, M. Index of Garden Plants; Timber Press: Portland, OR, USA, 1994.

32. Cavanagh, H.M.A.; Wilkinson, J. Biological activities of lavender essential oil. Phytother. Res. 2002, 16, 301-308. [CrossRef]

33. Kasper, S.; Gastpar, M.; Müller, W.E.; Volz, H.P.; Möller, H.J.; Dienel, A.; Schläfke, S. Silexan, an orally administered Lavandula oil preparation, is effective in the treatment of 'subsyndromal' anxiety disorder: A randomized, double-blind, placebo controlled trial. Int. Clin. Psychopharm. 2010, 25, 277-287. [CrossRef]

34. Perry, R.; Terry, R.; Watson, L.K.; Ernst, E. Is lavender an anxiolytic drug? A systematic review of randomised clinical trials. Phytomedicine 2012, 19, 825-835.

35. Nordquist, J.; Wilson, D.R. What Are the Health Benefits and Risk of Lavender? Medical News Today, 2020. Available online: https://www.medicalnewstoday.com/articles/265922 (accessed on 21 August 2020).

36. Expanded Commission E monograph: Lavender Flower. Integrative Medicine Communications, Germany; from the American Botanical Council. 2000. Available online: http://cms.herbalgram. org/commissione/index.html?gclid=Cj0KCQjw4f35BRDBARIsAPePBHwWR3JEzM7AR3COFj_ cQ0BhZa0htXPXeUqJq1htvEeZw5eOZMjFlZQaAkEZEALw_wcB\&ts=1598029641\&signature= 1cad5789340eb293a7b7775280d709b5 (accessed on 10 August 2020).

37. Lis-Balchin, M.; Hart, S. Studies on the mode of action of the essentials oil of lavender (Lavandula angustifolia P. Miller). Phytother. Res. 1999, 13, 540-542. [CrossRef]

38. Stanojevic, L.; Stanojevic, M.; Cakic, M.; Nikolic, V.; Nikolic, L. The effect of hydrodistillation techniques on field, kinetics, composition and antibacterial activity of Essentials oils from flowers of Lavandula officinalis L. Hem. Ind. 2011, 65, 455-463. [CrossRef]

39. Koulivand, P.H.; Ghadiri, M.K.; Gorji, A. Lavender and the nervous system. Evid. Based Complement. Alternat. Med. 2013, 2013, 681304. [CrossRef]

40. Fismer, K.L.; Pilkington, K. Lavender and sleep: A systematic review of the evidence. Eur. J. Integr. Med. 2012, 4, 436-447. [CrossRef] 
41. Kains, M.G. Culinary Herbs: Their Cultivation Harvesting Curing and Uses; Orange Judd Company: New York, NY, USA, 1912; Available online: https://www.amazon.com/Culinary-Herbs-Cultivation-Harvesting-Curingebook/dp/B004TRELJ6\#reader_B018PJ9BNO (accessed on 13 August 2020).

42. Bagget, N. The Art of Cooking with Lavender; Kitchenslane Productions: Columbia, MD, USA, 2016.

43. Perry, D. How to Cook with Lavender Bon Appetite. 2015. Available online: https://www.bonappetit.com/ test-kitchen/how-to/article/cooking-with-lavender (accessed on 15 August 2020).

44. Kremenchuk, R.I.; Kitaev, O.I. Estimation of lavender (Lavandula angustifolia) frost resistance. J. Appl. Res. Plant Variety Stud. Protect. 2017, 13, 155-161.

45. Zarnowski, R.; Suzuki, Y. Expedient Soxhlet extraction of resorcinolic lipids from wheat grains. J. Food Compos. Anal. 2004, 17, 649-664. [CrossRef]

46. Polish Standards, PN-75/A-04018; Polish Committee for Standardization: Warsaw, Poland, 1975; Available online: https://www.pkn.pl/en (accessed on 10 March 2020).

47. Oren, R.; Werk, K.S.; Buchmann, N.; Zimmermann, R. Chlorophyll-nutrient relationships identify nutritionally caused decline in Piceaabies stands. Can. J. Forest Res. 1993, 23, 1187-1195. [CrossRef]

48. Kopec, R.E.; Cooperstone, J.L.; Cichon, M.J.; Schwartz, S.J. Analysis Methods of carotenoids. In Analysis of Antioxidant Rich Phytochemicals; Xu, Z., Luke, R., Howard, L.R., Eds.; John Wiley \& Sons: New York, NY, USA, 2012.

49. Al Majidi, H.M.I.; Al Qubury, H.Y. Determination of vitamin C (ascorbic acid) contents in various fruit and vegetable by UV-spectrophotometry and titration methods. J. Chem. Pharm. Sci. 2016, 9, 2972-2974.

50. Wesolowska, A.; Grzeszczuk, M.; Jadczak, D. Comparison of chemical compositions of essential oils isolated by hydrodistillation from wild thyme (Thymus serpyllum L.) with use of Deryng and Clevenger apparatus. Herba Polon. 2014, 60, 7-17. [CrossRef]

51. Duncan, D.B. Multiple range and multiple F tests. Biometrics 1955, 11, 1-42. [CrossRef]

52. Buchanan, B.B.; Gruissem, W.; Jones, R.J. Biochemistry and Molecular Biology of Plants, 2nd ed.; Wiley: Blackwell, MA, USA, 2000.

53. Brown, S.A. Biosynthesis of the coumarins IV. The formation of coumarin and herniarin in lavender. Phytochemistry 1963, 2, 7-144. [CrossRef]

54. Zámboriné Németh, E.; Nguyen, H.T. Thujone, a widely debated volatile compound: What do we know about it? Phytochem. Revs. 2020, 19, 405-423. [CrossRef]

55. Salehi, B.; Upadhyay, S.; Orhan, I.E.; Arun Kumar Jugran, A.K.; Jayaweera, S.L.D.; Dias, D.A.; Sharopov, F.; Taheri, Y.; Martins, N.; Baghalpour, N.; et al. Therapeutic potential of $\alpha$ - and $\beta$-pinene: A miracle gift of nature. Biomolecules 2019, 9, 738. [CrossRef]

56. Mr. HempFlower, Ocimene: The Lesser Known Terpene with Amazing Benefits. Available online: https://mrhempflower.com/ocimene/ (accessed on 8 September 2020).

57. Grys, A.; Łowicki, Z.; Gryszczyńska, A.; Kania, M.; Parus, A. Herbal plants in the treatment of skin diseases-Security and application. Borgis Post. Fitoter. 2011, 3, 191-196. (In Polish)

58. Wilkerson, R.D.; Henderson, J.D. Antiarrhythmic activity of amitriptyline analogues in conscious dogs after myocardial infarction: Cyproheptadinium methiodide. J. Med.Chem. 1980, 23, 1255-1258. [CrossRef] [PubMed]

59. Fujiwara, T.; Ohira, K.; Urushibara, K.; Ito, A.; Yoshida, M.; Kanai, M.; Tanatani, A.; Kagechika, H.; Hirano, T. Steric structure and activity relationship of cyproheptadine derivatives as inhibitors of histone methyltransferase Set7/9. Bioorg. Med. Chem. 2016, 24, 4318-4323. [CrossRef] [PubMed]

60. Bilikiewicz, A.; Pużyński, S.; Wciórka, J.; Rybakowski, J. Psychiatry; Urban \& Parner: Wrocław, Poland, 2003; Volume 2, p. 526. ISBN 83-87944-72-6. (In Polish)

61. Borg-Karlson, A.K.; Norin, T.; Talvitie, A. Configurations and conformations of torreyol ( $\delta$-cadinol), $\alpha$-cadinol, T-murolol and T-cadinol. Tetrahedron. 1981, 37, 425-430. [CrossRef]

62. Bartnik, M.; Facey, P.C.; Glycosides, P.C. Pharmacognosy; Badal, S., Delgoda, R., Eds.; Elsevier: Amsterdam, The Netherlands, 2017; Chapter 8. 
63. Sallaud, C.; Rontein, D.; Onillon, S.; Jabes, F.; Duffe, P.; Giacalone, C.; Thoraval, S.; Escoffier, C.; Herbette, G.; Leonhardt, N.; et al. A Novel pathway for sesquiterpene biosynthesis from Z,Z-fernesyl pyrophosphate in the wild tomato solanum habrochaites. Plant. Cell 2009, 21, 301-317. [CrossRef] [PubMed]

64. Sapir-Mir, M.; Mett, A.; Belausov, E.; Tal-Mashulam, S.; Frydman, A.; Gidoni, D.; Eyal, Y. Peroxisomal localization of arabidopsis isopentenyl diphosphate isomerases suggests that part of the plant isoprenoid mevalonic acid pathway is compartmentalized to peroxisomes. Plant. Physiol. 2008, 148, 1219-1228. [CrossRef] [PubMed]

Publisher's Note: MDPI stays neutral with regard to jurisdictional claims in published maps and institutional affiliations.

(C) 2020 by the authors. Licensee MDPI, Basel, Switzerland. This article is an open access article distributed under the terms and conditions of the Creative Commons Attribution (CC BY) license (http://creativecommons.org/licenses/by/4.0/). 